Bibliography on Woodland and Caddo Instrumental Neutron Activation Analysis and Petrographic Analysis Studies in East Texas, Northwest Louisiana, eastern Oklahoma, and Southwest Arkansas

Timothy K. Perttula Heritage Research Center, Stephen F. Austin State University

Robert Z. Selden Jr. Heritage Research Center, Stephen F. Austin State University

Follow this and additional works at: https://scholarworks.sfasu.edu/ita

Part of the American Material Culture Commons, Archaeological Anthropology Commons, Environmental Studies Commons, Other American Studies Commons, Other Arts and Humanities Commons, Other History of Art, Architecture, and Archaeology Commons, and the United States History Commons

Tell us how this article helped you.

This Article is brought to you for free and open access by the Center for Regional Heritage Research at SFA ScholarWorks. It has been accepted for inclusion in Index of Texas Archaeology: Open Access Gray Literature from the Lone Star State by an authorized editor of SFA ScholarWorks. For more information, please contact cdsscholarworks@sfasu.edu. 


\section{Bibliography on Woodland and Caddo Instrumental Neutron Activation Analysis}

and Petrographic Analysis Studies in East Texas, Northwest Louisiana, eastern Oklahoma, and Southwest Arkansas

Creative Commons License

\section{(c) (1) (9)}

This work is licensed under a Creative Commons Attribution-NonCommercial 4.0 International License 


\title{
BIBLIOGRAPHY ON WOODLAND AND CADDO INSTRUMENTAL NEUTRON ACTIVATION ANALYSIS AND Petrographic Analysis Studies in East TeXas, NorthWEST LOUISIANA, EASTERN OKLAHOMA, AND SOUTHWEST ARKANSAS
}

\author{
Timothy K. Perttula and Robert Z. Selden, Jr.
}

Characterizing the chemical and mineralogical composition of ceramic vessels and sherds from Woodland and Caddo sites by means of instrumental neutron activation analysis (INAA) and petrographic analysis provides a unique opportunity to gather and investigate empirical evidence from ceramic vessels (and perhaps their contents?) on their trade and exchange at varying scales conducted by ancestral Caddo people with their neighbors, both near and far (i.e., other ancestral Caddo groups as well as non-Caddo communities) (see Perttula 2002a). This evidence in turn can be used to explore changes in the nature of social and economic relationships between particular Caddo groups and other prehistoric populations. Identified compositional and paste differences that have been identified between the different wares made by Caddo groups (i.e., plain wares, utility wares, and fine wares) have also been employed to explore functional and technological differences in vessel function and form (see Perttula 2000i:138).

According to Ferguson et al. (2012a:224), the database of INAA samples of ceramic sherds from Woodland and Caddo sites that have been analyzed at the University of Missouri Research Reactor Center at the University of Missouri-Columbia, "consist[s] of more than 1000 ceramic samples...[and] is one of the largest samples from any region in the world. It is also one of the most complicated. Over the past decade the compositional group structure has undergone numerous modifications, as well as a complete reanalysis [Ferguson et. al 2010]. The most recent interpretation of the East Texas Caddo database divides the region into 11 sub-regions." Each of these sub-regions (Figure 1) has then been treated as an individual dataset, and for most sub-regions, a core group has been defined and identified. This INAA sample has been gathered from more than 200 Woodland and Caddo sites/ceramic assemblages in the Caddo area, and the petrographic sample is almost equally as robust.

A considerable amount of work has been completed in Caddo area ceramic studies over the last 15 years-although the first contributions to this manner of analysis occurred more than 40 years ago (see Bareis and Porter 1965; Porter 1971) — that have focused on issues of technological organization and ceramic provenance and whether particular vessels and sherds from vessels from Woodland and Caddo sites were manufactured locally or were the product of trade and exchange from non-local production sources. However, most of this work has been conducted in contexts-especially cultural resource management projects-where the results of these studies are to be found only within in very limited distribution reports and publications. Thus, many archeologists that currently work in the Caddo area may not be aware of the scope and breadth of the research that has been accomplished to date, nor are they aware of the primary published (and unpublished) literature on the subject. Consequently, we have assembled a bibliography of all known (current through October 2012) reports and publications that address with INAA and petrographic analyses of ceramic vessels and ceramic vessel sherds in the Caddo area. 


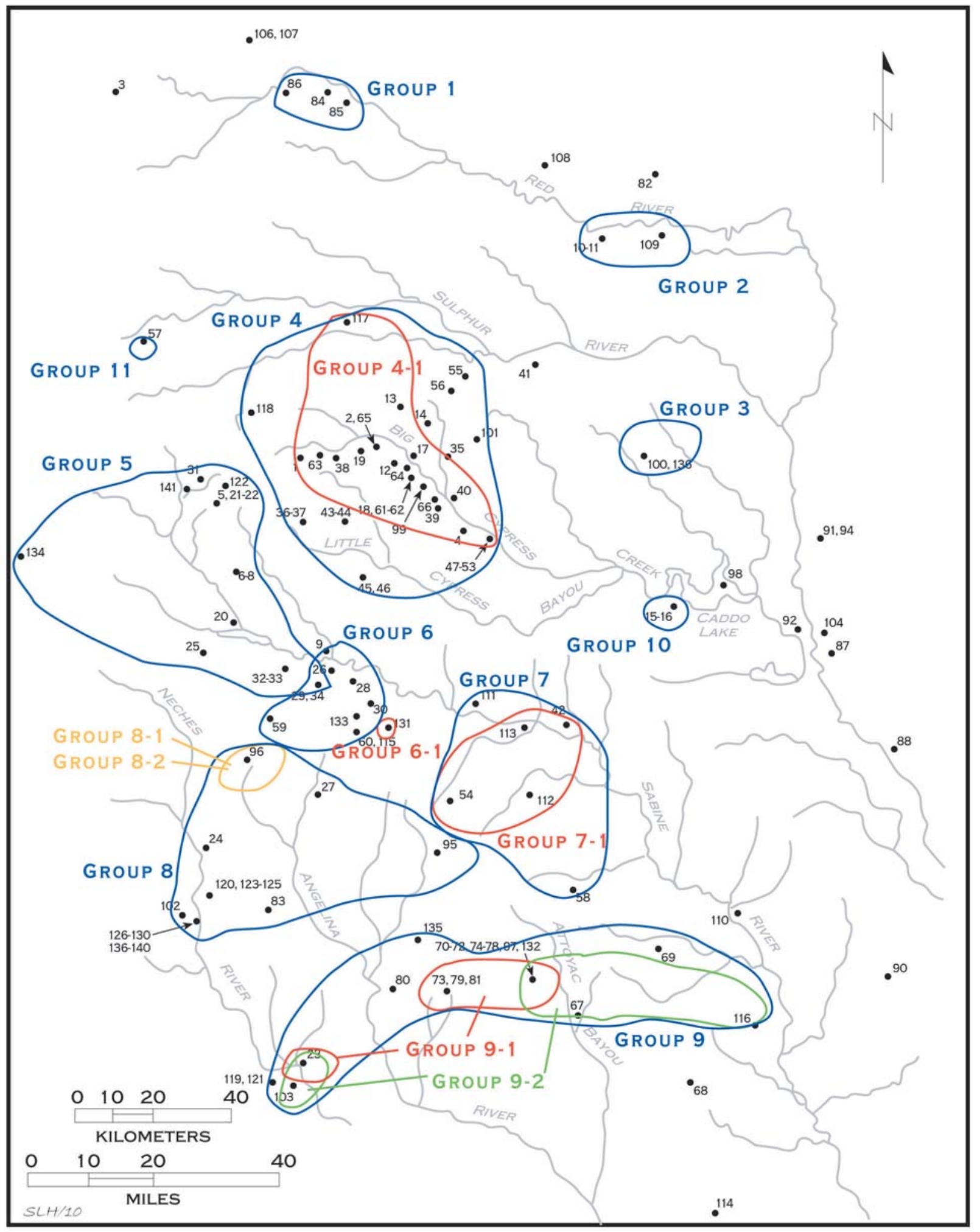

Figure 1. Current Chemical Groups defined in INAA analyses of sherds, mainly in sites in East Texas. 
As evidenced by the bibliography shows, the vast majority of the INAA and petrographic analysis studies completed to date on Woodland and Caddo sites in the Caddo area have been conducted on ceramics from sites in East Texas. We think it is important that comparable studies be completed on Woodland and Caddo vessels and vessel sherds from assemblages in adjoining states, and this article is a plea to Caddo archeologists working in all parts of the Caddo area that they strongly consider undertaking their own INAA and petrographic research. Such research can (1) help to better clarify the compositional nature of these ceramic wares across the entire Caddo temporal and geographic landscape, not being limited to just one part of the Caddo world; (2) help pinpoint other ceramic manufacturing locales and chemical/mineralogical compositional groups, but also to assess their apparent technological complexity; and (3) lead to better evaluations of the regional character of prehistoric and historic Woodland and Caddo trade and interaction networks (which crossed our modern political boundaries) that existed, and more definitively establish whether there were changes through time in the direction and intensity of local and long distance trade and interaction. The disparate pieces of information contained within the sherds and vessel fragments of Woodland and Caddo ceramics found on many prehistoric and early historic sites throughout a broad region have the potential to address these questions and research issues, and can contribute unique information concerning those relationships that existed in the distant (and not-so-distant) past between Woodland groups and Caddo farmers and other aboriginal groups in the Southeast, Midwest, and Southern Plains.

\section{Acknowledgments}

We thank Ann Early, Linda Ellis, Ross Fields, Jeff Girard, and Mary Beth Trubitt for their helpful suggestions regarding instrumental neutron activation analysis and petrographic work completed in and very near the Caddo area.

Bareis, C. J. and J. W. Porter

\section{Bibliography}

1965 Megascopic and Petrographic Analyses of a Foreign Pottery Vessel from the Cahokia Site. American Antiquity 31(1):95-101.

Cecil, L. G.

2012a Petrographic Analysis of Pottery and Clay Samples from the Pine Tree Mound Site (41HS15), Harrison County, Texas. In Archeology of the Nadaco Caddo: The View from the Pine Tree Mound Site (41HS15), Harrison County, Texas, edited by R. C. Fields and E. F. Gadus, Appendix D. Reports of Investigations No. 164. Prewitt and Associates, Inc., Austin.

2012b Petrographic Report for Pottery and Burned Clay/Daub Samples from 41CP220 and 41CP21 Sites, Camp County, Texas. MS on file, Ama Terra Environmental, Inc., Austin.

2012c Petrographic Report for Pottery from the Tankersley Creek Sites (41TT851, 41TT852, and 41TT853), Titus County, Texas. Report on file, Prewitt and Associates, Inc., Austin.

Cogswell, J. W., H. Neff, and M. D. Glascock

1998 Chemical Variation in Northeastern Texas Ceramics. University of Missouri Research Reactor, Columbia.

2000 Continued Investigations of Ceramic Exchange Among the Prehistoric Caddoan: Compositional Evidence. University of Missouri Research Reactor, Columbia.

2004 Chemical Variation in Northeast Texas Ceramics. In The Oak Hill Village Site (41RK214), Rusk County, Texas, by R. Rogers and T. K. Perttula, pp. 307-321. Document No. 030083. PBS\&J, Austin. 
Cogswell, J. W., H. Neff, and M. D. Glascock

2005 Instrumental Neutron Activation Analysis of Ceramics from Residential Areas at the Pilgrim's Pride Site. In Archeological Investigations at the Pilgrim's Pride Site (41CP304), a Titus Phase Community in the Big Cypress Creek Basin, Camp County, Texas, edited by T. K. Perttula, pp. 148-161. 2 Vols. Report of Investigations No. 30. Archeological \& Environmental Consultants, LLC, Austin.

2008 Chemical Variation in Northeastern Texas Ceramics, Including Analyses of Shreds from Four Red River County Sites. In "The Archeology of the Roitsch Site (41RR16), an Early to Historic Caddo Period Village on the Red River in Northeast Texas," edited by T. K. Perttula, pp. 402-413. In Collected Papers from Past Texas Archeological Society Summer Field Schools, edited by T. K. Perttula. Special Publication No. 5, Texas Archeological Society, San Antonio.

Cogswell, J. W., H. Neff, M. Glascock, and T. K. Perttula

2005 Instrumental Neutron Activation Analysis of Vessel Ceramics from the Titus Phase Cemetery. In Archeological Investigations at the Pilgrim's Pride Site (41CP304), a Titus Phase Community in the Big Cypress Creek Basin, Camp County, Texas, edited by T. K. Perttula, pp. 281-283. 2 Vols. Report of Investigations No. 30. Archeological \& Environmental Consultants, LLC, Austin.

Descantes, C. D. Creel, R. J. Speakman, S. Wilson, and M. D. Glascock

2005 Instrumental Neutron Activation Analysis of Pottery from the George C. Davis Site, Texas. North American Archaeologist 25(2):121-138.

Descantes, C., R. J. Speakman, and M. D. Glascock

2003a Letter Report to Timothy K. Perttula with enclosed figures and tables, September 3, 2003. University of Missouri Research Reactor, Columbia.

2003b Addendum to September 3, 2003 Letter Report to Timothy K. Perttula with enclosed figures and tables, November 17, 2003. University of Missouri Research Reactor, Columbia.

2003c Neutron Activation Analysis of Pottery from the George C. Davis Site, Texas. Letter report to Drs. Darrell Creel and Samuel Wilson, December 5, 2003. University of Missouri Research Reactor, Columbia.

2007 Instrumental Neutron Activation Analysis of Pottery from Four Caddoan Sites at the Barksdale AFB, Louisiana. In Barksdale Air Force Base, Louisiana: National Register Evaluative Testing at Prehistoric Sites 16B0450, 16B0458, and 16B0473, Barksdale Air Force Base, Bossier Parish, Louisiana, by C. Lintz, F. Largent, T. Perttula, V. Dongarra, M. Prior, and M. Huhnke, pp. G-1 to G-17. Report of Investigations No. 37. United States Air Force Headquarters Air Combat Command Series.

2011 Instrumental Neutron Activation Analysis. In Barksdale Air Force Base, Louisiana: National register Evaluative Testing at Sites 16B0453, 16B0454, 16B0476, 16B0477, and 16B0531, Barksdale Air Force Base, Bossier Parish, Louisiana, by M. M. Green, C. Lintz, M. D. Freeman, A. Burkholder, and T. K. Perttula, pp. E-1 to E-3. Report of Investigations No. 57. United States Air Force Headquarters Air Combat Command Series.

Ennes, M. J., with contributions by M. B. Cliff

1997 Petrographic Analysis of Prehistoric Ceramics Recovered from Sites 41BW553 and 41TT670. In Cultural Resources Testing of Two Sites within the White Oak Creek Wildlife Management Area, Bowie and Titus Counties, Texas, by F. B. Largent, Jr., D. L. Beene, M. B. Cliff, and S. M. Hunt, pp. G-1 to G-22. White Oak Creek Mitigation Area Archeological Technical Series, Report of Investigations No. 6. Geo-Marine, Inc., Plano. 
Ferguson, J. R.

2009 Letter Report to Timothy K. Perttula with enclosed figures and tables, April 29, 2009. Research Reactor Center, University of Missouri-Columbia.

2010 Preliminary Report on the Reanalysis of the Texas Caddo NAA Database. In Studies on the Instrumental Neutron Activation Analysis of Woodland Period and Caddo Tradition Ceramics from Eastern Texas, compiled by T. K. Perttula, Article 1. Special Publication No. 17. Friends of Northeast Texas Archaeology, Austin and Pittsburg.

Ferguson, J. R. and M. D. Glascock

2006 Instrumental Neutron Activation Analysis of Caddoan Pottery and Clay Samples from Texas and Louisiana. Research Reactor Center, University of Missouri, Columbia.

2007 Instrumental Neutron Activation Analysis of Caddo Pottery from Ten Sites in Eastern Texas. Letter report to Timothy K. Perttula with enclosed figures and tables, July 16, 2007. Research Reactor Center, University of Missouri, Columbia.

2008a Instrumental Neutron Activation Analysis of Caddo Pottery and Clay Samples from the Leaning Rock Site. In "Life on Jackson Creek, Smith County, Texas: Archeological Investigations of a $14^{\text {th }}$ Century Caddo Domicile at the Leaning Rock Site (41SM325)," by M. Walters. Caddo Archeology Journal 17:49-61.

2008b Appendix 13, Instrumental Neutron Activation Analysis of Caddo Pottery and Clay Samples from Texas and Louisiana. In Lake Naconiche Archeology, Nacogdoches County, Texas: Results of the Data Recovery Excavations at Five Prehistoric Archeological Sites, edited by T. K. Perttula, pp. A131 to A13-23. Report of Investigations No. 60, CD of Appendices. Archeological \& Environmental Consultants, LLC, Austin.

2009a Instrumental Neutron Activation Analysis of Caddo Ceramics from the Ear Spool Site, 41TT653, in Northeastern Texas. In Data Recovery Investigations at the Ear Spool Site (41TT653), Titus County, Texas, by T. K. Perttula and D. L. Sherman, pp. 265-277. Document No. 070205. PBS\&J, Austin.

2009b Letter Report to Timothy K. Perttula with enclosed figures and tables, April 29, 2009. Research Reactor Center, University of Missouri, Columbia.

2010a Instrumental Neutron Activation Analysis of Ceramic Samples from 41CP28, Camp County, Texas. In National Register of Historic Places Eligibility Testing on Three Late Prehistoric Sites (41CP28, 41CP88 and 41CP414) Within the Leesburg Mine, Camp County, Texas, by D. L. Sherman, L. W. Ellis, C. Heligenstein, S. Laurence, R. Rogers, H. Rush, J. Shipp, and C. Wallace, pp. Appendix A1-1 to A1-11. PBS\&J, Austin.

2010b Instrumental Neutron Activation Analysis of Ceramic Samples from 41CP88, Camp County, Texas. In National Register of Historic Places Eligibility Testing on Three Late Prehistoric Sites (41CP28, 41CP88 and 41CP414) Within the Leesburg Mine, Camp County, Texas, by D. L. Sherman, L. W. Ellis, C. Heligenstein, S. Laurence, R. Rogers, H. Rush, J. Shipp, and C. Wallace, pp. A1-13 to A1-23. PBS\&J, Austin.

2011a Instrumental Neutron Activation Analysis of Caddo Pottery from Ten Sites in Eastern Texas. In Archeological Investigations at the Lang Pasture Site (41AN38) in the Upper Neches River Basin of East Texas, assembled and edited by T. K. Perttula, D. B. Kelley, and R. A. Ricklis, pp. 591-612. Report 129, Archeological Studies program, Environmental Affairs Division, Texas Department of Transportation, Austin.

2011b Instrumental Neutron Activation Analysis of Ceramic Samples from 41CP408, Camp County, Texas. Letter report to Linda Ellis with enclosed figures and tables, November 29, 2011. Research Reactor Center, University of Missouri, Columbia. 
Ferguson, J. R. and M. D. Glascock

2012a Instrumental Neutron Activation Analysis of Ceramic and Clay Samples from the Pine Tree Mound Site (41HS15), Harrison County, Texas. In Archeology of the Nadaco Caddo: The View from the Pine Tree Mound Site (41HS15), Harrison County, Texas, edited by R. C. Fields and E. F. Gadus, Appendix C. Reports of Investigations No. 164. Prewitt and Associates, Inc., Austin.

2012b Instrumental Neutron Activation Analysis of Ceramic and Burned Clay Samples from 41CP220 and 41CP21, Camp County, Texas. Archaeometry Laboratory, Research Reactor center, University of Missouri, Columbia.

2012c Neutron Activation Analysis of Caddo Ceramics from Three Sites in Titus County, Texas. Archaeometry Laboratory, Research Reactor Center, University of Missouri, Columbia.

2012d Neutron Activation analysis of Caddo Ceramics from 41PN175, Panola County, Texas. Letter report to Duane Peter with enclosed figures and tables, July 5, 2012. Archaeometry Laboratory, Research Reactor Center, University of Missouri, Columbia.

Ferguson, J. R., M. D. Glascock, D. G. Robinson, and T. K. Perttula

2012 Instrumental Neutron Activation Analysis and Petrographic Analysis of Ceramic Sherds. In The Hickory Hill Site (41CP408): Archeological Investigations at a Middle Caddo Site in the Little Cypress Creek Basin in East Texas, by T. K. Perttula and L. W. Ellis, pp. 215-254. Document No. 120055. Atkins, Austin.

Ferguson, J. R., T. K. Perttula, and M. D. Glascock

2010 Dividing Up the Caddo Cultural Landscape: Small-Scale Analysis of a Large Ceramic INAA Database. In Studies on the Instrumental Neutron Activation Analysis of Woodland and Caddo Tradition Ceramics from Eastern Texas, compiled by T. K. Perttula. Article 2, Special Publication No. 17. Friends of Northeast Texas Archaeology, Austin and Pittsburg.

Ferring, C. R., and T. K. Perttula

1987 Defining the Provenance of Red-Slipped Pottery from Texas and Oklahoma by Petrographic Methods. Journal of Archaeological Science 14:437-456.

Iruegas, S. A.

1999 The Petrographic Analysis of Caddoan Ceramics from the Hurricane Hill Site (41HP106), Hopkins County, Texas. In The Hurricane Hill Site (41HP106): The Archaeology of a Late Archaic/Early Ceramic and Early-Middle Caddoan Settlement in Northeast Texas, edited by T. K. Perttula, pp. 279-290. 2 Vols. Special Publication No. 4. Friends of Northeast Texas Archaeology, Pittsburg and Austin.

2000 Petrographic Analysis of Caddoan Ceramics from Caddoan and Non-Caddoan Sites in Texas, Kansas, and Illinois. Letter Report No. 69. Archeological \& Environmental Consultants, Austin.

Neff, H.

2000 Letter Report to Timothy K. Perttula with enclosed figures and tables, March 29, 2000. University of Missouri Research Reactor, Columbia.

2001 Letter Report to Timothy K. Perttula with enclosed figures and tables, December 19, 2001. University of Missouri Research Reactor, Columbia.

2002 Instrumental Neutron Activation Analysis. In Data Recovery Excavations at the McGuire's Garden Site (41FT425), Jewett Mine, Freestone County, Texas, by E. F. Gadus, J. K. McWilliams, and R. C. Fields, pp. 239-246. Report of Investigations No. 134. Prewitt and Associates, Inc., Austin. 
Neff, $\mathrm{H}$.

2008 Review of Ceramic Compositional Studies from In and Around the Mississippi Valley. In Time's River: Archaeological Syntheses from the Lower Mississippi River Valley, edited by J. Rafferty and E. Peacock, pp. 223-242. University of Alabama Press, Tuscaloosa.

2009 Instrumental Neutron Activation Analysis Results from an Initial Study of Ear Spool Site Ceramic Sherds. In Data Recovery Investigations at the Ear Spool Site (41TT653), Titus County, Texas, by T. K. Perttula and D. L. Sherman, pp. C-1 to C-11. Document No. 070205. PBS\&J, Austin.

Neff, H. and M. D. Glascock

2000 Compositional Variation in Caddoan and Other Ceramics from Northeastern Texas: Update on Results of Instrumental Neutron Activation Analysis. University of Missouri Research Reactor, Columbia.

2005 Compositional Variation in Aboriginal Ceramics from Central Texas: Results of Instrumental Neutron Activation Analysis. In Analysis and Reporting for 41FY135, The Sandbur Site, Fayette County, Texas, by A. J. Kalter, R. M. Rogers, and M. N. Smith, pp. C-5 to C-35. Archeological Studies program Report No. 73. Texas Department of Transportation, Austin.

Neff, H., J. W. Cogswell, and M. D. Glascock

1996 Compositional Analysis of Caddoan Ceramics from Northeast Texas. University of Missouri Research Reactor, Columbia.

1998 Compositional Analysis of Caddoan Ceramics from the Mockingbird Site (41TT550) in Northeast Texas. In Analysis of the Titus Phase Mortuary Assemblageat the Mockingbirdor "Kahbakayammaahin" Site (41TT550), by T. K. Perttula, M. Tate, H. Neff, J. W. Cogswell, M. D. Glascock, E. Skokan, S. Mulholland, R. Rogers, and B. Nelson, pp. 255-272. Document No. 970849. Espey, Huston \& Associates, Inc., Austin.

1999 Compositional Analysis of Caddoan Ceramics from Northeast Texas. In The Hurricane Hill Site (41HP106): The Archaeology of a Late Archaic/Early Ceramic and Early-Middle Caddoan Settlement in Northeast Texas, edited by T. K. Perttula, pp. 301-319. 2 Vols. Special Publication No. 4. Friends of Northeast Texas Archaeology, Pittsburg and Austin.

Perttula, T. K.

1999 Regional Comparisons in Paste Composition from Petrographic Analyses. In The Hurricane Hill Site (41HP106): The Archaeology of a Late Archaic/Early Ceramic and Early-Middle Caddoan Settlement in Northeast Texas, edited by T. K. Perttula, pp. 291-297. 2 Vols. Special Publication No. 4. Friends of Northeast Texas Archaeology, Pittsburg and Austin.

2000a Results of the Instrumental Neutron Activation Analysis of Caddo Vessel Sherds from the Helm Site (3HS449). In Data Recovery at the Helm Site, 3HS449, Hot Spring County, Arkansas, by R. H. Lafferty, A. M. Early, M. C. Sierzchula, M. C. Hill, G. S. Powell, N. H. Lopinot, L. S. Cummings, S. L. Scott, S. K. Nash, and T. K. Perttula, pp. G-1 to G-5. MCRA Report 2000-1. Mid-Continental Research Associates, Inc., Lowell, Arkansas.

2000b Results of the Instrumental Neutron Activation Analysis of a Holly Fine Engraved Vessel Sherd from the Audrey Site (11GE20). Letter Report No. 66. Archeological \& Environmental Consultants, Austin.

2000c Results of the Instrumental Neutron Activation Analysis of Woodland and Caddoan Sherds from the Washington Square (41NA49), Mast (41NA157), Guadalupe del Pilar (41NA223) and Mission Dolores de los Ais (41SA125) Sites in East Texas. Letter Report No. 76. Archeological \& Environmental Consultants, Austin. 
Perttula, T. K.

$2000 \mathrm{~d}$ Results of the Instrumental Neutron Activation Analysis of Caddo Vessel Sherds from the Tom Moore (41PN149), Hardy (41SM55), and Redwine (41SM193) Sites in Northeast Texas. Letter Report No. 68. Archeological \& Environmental Consultants, Austin.

2000e Results of the Instrumental Neutron Activation Analysis of Caddo Vessel Sherds from 41SY45, the Tyson (41SY92), and Henry M (41NA60) Sites in Northeast Texas. Letter Report No. 75. Archeological \& Environmental Consultants, Austin.

$2000 \mathrm{f}$ Instrumental Neutron Activation Analysis of Woodland Period and Caddo Vessel Sherds from Sites in Cherokee, Smith, and Wood Counties in Northeast Texas. Letter Report No. 85. Archeological \& Environmental Consultants, Austin.

2000g Trade Caddo Vessels in Plains Village Sites in South Central Kansas, Cowley County, Kansas. Letter Report No. 71. Archeological \& Environmental Consultants, Austin.

2000h Analysis of Caddoan Ceramics from Five Prehistoric or Protohistoric Lower Walnut Focus Sites in the Vicinity of Arkansas City, Kansas. Letter Report No. 70. Archeological \& Environmental Consultants, Austin.

2000i Functional and Stylistic Analyses of Ceramic Vessels from Mortuary Features at a $15^{\text {th }}$ and $16^{\text {th }}$ Century Caddo Site in Northeast Texas. Midcontinental Journal of Archaeology 25(1):101-151.

2001 Instrumental Neutron Activation Analysis of Caddo Sherds from Lake O' The Pines. In Archeological Investigations at the Camp Joy Mound (41UR144): A Titus Phase Earthen Mound Site at Lake O' The Pines, Upshur County, Texas, by T. K. Perttula and B. Nelson, pp. 24-31. Report of Investigations No. 44. Archeological \& Environmental Consultants and Friends of Northeast Texas Archaeology, Austin and Pittsburg.

2002a Archaeological Evidence for the Long-Distance Exchange of Caddo Indian Ceramics in the Southern Plains, Midwest, and Southeastern Untied States. In Geochemical Evidence for Long-Distance Exchange, edited by M. D. Glascock, pp. 89-107. Bergin and Garvey, Westport, Connecticut.

2002b Instrumental Neutron Activation Analysis of Vessel Sherds from Sites on U.S. Forest Service Lands in Houston, Sabine, Shelby, and Walker Counties in East Texas. Letter Report No. 116. Archeological \& Environmental Consultants, LLC, Austin.

2003a Instrumental Neutron Activation Analysis of Ceramic Sherds from Los Adaes (16NA16) in Northwest Louisiana. Letter Report No. 144. Archeological \& Environmental Consultants, LLC, Austin.

2003b Instrumental Neutron Activation Analysis of Ceramic Sherds from 16B0327, 16CD12, 16CD218, 16DS268, 16DS380, and 16NA587 in Northwestern Louisiana. Letter Report No. 143. Archeological \& Environmental Consultants, LLC, Austin.

2003c Results of the Instrumental Neutron Activation Analysis of Caddo Ceramic Sherds from the Nawi haia ina Site. In The Nawi haia ina Site (41RK170): Archeological Investigations in the City of Henderson's Southside Wastewater Treatment Plant, Rusk County, Texas, by T. K. Perttula and B. Nelson, pp. 334-336. Report of Investigations No. 51. Archeological \& Environmental Consultants, LLC, Austin.

2004 Results of the INAA Analysis of Ceramic Sherds from 41SM273. In Woodland and Caddo Archeology at the Broadway or Kanduts'ah Kuhnihdahahdisa' Site (41SM273) on the City of Tyler-Lake Palestine WTP Project, Smith County, Texas, by T. K. Perttula and B. Nelson, pp. 413-419. Report of Investigations No. 50. Archeological and Environmental Consultants, LLC, Austin.

2010 (compiler) Studies on the Instrumental Neutron Activation Analysis of Woodland Period and Caddo Tradition Ceramics from Eastern Texas. Special Publication No. 17. Friends of Northeast Texas Archaeology, Pittsburg and Austin. 
Perttula, T. K. and J. R. Ferguson

2010 The Chemical Variation in Prehistoric and Early Historic Caddo Ceramics in Eastern Texas. In Studies on the Instrumental Neutron Activation Analysis of Woodland Period and Caddo Tradition Ceramics from Eastern Texas, compiled by T. K. Perttula, Article 3. Special Publication No. 17. Friends of Northeast Texas Archaeology, Austin and Pittsburg.

Perttula, T. K., M. F. Hawley, and F. W. Scott

2002 Caddo Trade Ceramics. Southeastern Archaeology 20(2):154-172.

Perttula, T. K., S. A. Iruegas, and H. Neff

2003 Caddoan Pottery in Central Texas: Geochemical Analyses of Ceramics from Fort Hood and Vicinity. Research Report No. 51. Archeological Resource Management Series, United States Army Fort Hood.

Perttula, T. K., D. G. Robinson, J. R. Ferguson, and M. D. Glascock

2010 Analysis of Aboriginal Ceramic Sherds. In National Register Testing at 41BQ285, Bosque County, Texas: FM 56 Bridge Replacement at the North Bosque River, by T. B. Griffith, K. W. Kibler, and D. K. Boyd, pp. 85-104. Archeological Studies Program, Report No. 101. Environmental Affairs Division, Texas Department of Transportation, Austin.

Porter, J. W.

1971 Thin-Section Identifications of Spiro Sherds. In Spiro Studies, Volume 3: Pottery Vessels, by J. A. Brown, pp. 244-246. First Part of the Third Annual Report of Caddoan Archaeology—Spiro Focus Research. Stovall Museum of Science and History, University of Oklahoma and The University of Oklahoma Research Institute, Norman.

Reed, H., R. J. Hoard, R. J. Speakman, and M. Glascock

2005 A Caddoan-Style Sherd from Marion County, Kansas: Surprising Results from Compositional Analysis. The Kansas Anthropologist 26:1-7.

Reese-Taylor, K.

1993 Petrographic Analysis of Caddo Ceramics from Titus County, Northeast Texas. In Archaeological Investigations within the Monticello B-2 First Five Year Disturbance Area, Titus County, Texas, by S. M. Kotter, R. Rogers, R. Taylor, K. Reese-Taylor, and W. E. Glander, pp. A-1 to A-13. Document No. 920013. Espey, Huston \& Associates, Inc., Austin.

1994 Petrographic Analysis of Caddoan Ceramics from Rusk County, Texas. In National register Testing of Eight Archaeological Sites within the Oak Hill 2,280 Acre Study Area, Rusk County, Texas, by R. Rogers, E. Foster, and K. Reese-Taylor, pp. B-1 to B-15. Document No. 930169. Espey, Huston \& Associates, Inc., Austin.

1995a Evidence of Resource Procurement and Manufacturing Techniques in Caddoan Ceramic Assemblages from the Sabine, Cypress, and Sulphur River Drainage Basins, Rusk and Titus Counties, Texas. Journal of Northeast Texas Archaeology 5:9-27.

1995b Petrographic Analysis of Ceramics. In National Register Testing of Ten Sites in the Monticello B-2 Surface Mine, Titus County, Texas, by M. A. Nash, S. M. Kotter, K. V. Reese-Taylor, E. A. Skokan, E. R. Foster, R. M. Rogers, and W. P. Glander, pp. C-1 to C-13. Document No. 930529. Espey, Huston \& Associates, Inc., Austin. 
Reese-Taylor, K.

1997 Petrographic Analysis of Ceramic Thin Sections from 41TT372, Titus County, Texas. In Data Recovery Excavations at Site 41 TT372 in the Tankersley Creek Watershed, Monticello B-2 Surface Mine, Titus County, Texas, by E. Barnhart, B. Dixon, S. Kotter, M. Nash, K. Reese-Taylor, E. Skokan, and R. Taylor, Appendix C. Document No. 940608. Espey Huston \& Associates, Inc., Austin.

Reese-Taylor, K., J. Hageman, and R. A. Ricklis

1995 Preliminary Paste Analyses of Ceramic Samples from the Mustang Branch (41HY209) and Barton Site (41HY202). In Archaic and Late Prehistoric Human Ecology in the Middle Onion Creek Valley, Hays County, Texas, by R. A. Ricklis and M. B. Collins, pp. 549-568. 2 Vols. Studies in Archeology 19. Texas Archeological Research Laboratory, The University of Texas at Austin.

Robinson, D. G.

2012a Petrographic Analysis of Ceramic Sherds from 41SM404. In National Register of Historic Places Eligibility Testing of Site 41SM404 within TxDOT's Tyler District, Smith County, Texas, by M. A. Nash, T. K. Perttula, and L. W. Ellis, pp. E-1 to E-13. Document No. 110055. Atkins, Austin.

2012b Petrographic Analysis. In Archeological Mitigation at the White Oak Shoals Plantation Site (3MI319), Miller County, Arkansas, by A. Stahman, M. Chavez, L. W. Ellis, and M. McWhorther, pp. 72-82. Document No. 110047. Atkins, Austin.

Rodriguez-Alegria, E., R. J. Speakman, and M. D. Glascock

2005 Instrumental Neutron Activation Analysis of Late Coles Creek/Early Mississippian Ceramics from the Tensas Basin, Louisiana. In Lake Providence: A Terminal Coles Creek Culture Mound Center, East Carroll Parish, Louisiana, edited by R. A. Weinstein, pp. 565-578. Coastal Environments, Inc., Baton Rouge.

Rogers, R.

2009 Petrographic Analysis of Ear Spool Site Caddo Ceramics (41TT653). In Data Recovery Investigations at the Ear Spool Site (41TT653), Titus County, Texas, by T. K. Perttula and D. L. Sherman, pp. D-7 to D-10. Document no. 070205. PBS\&J, Austin.

Shafer, J. R.

2009 Results of the Petrographic Analysis of Ceramics from Site 41TT653, Titus County, Texas. In Data Recovery Investigations at the Ear Spool Site (41TT653), Titus County, Texas, by T. K. Perttula and D. L. Sherman, pp. D-1 to D-6. Document no. 070205. PBS\&J, Austin.

Skokan, E. and T. K. Perttula

1998 The Petrographic Analysis of Ceramic Thin-Sections from the Mockingbird Site (41TT550), Titus County, Texas. In Analysis of the Titus Phase Mortuary Assemblage at the Mockingbird or "Kahbakayammaahin" Site (41TT550), by T. K. Perttula, M. Tate, H. Neff, J. W. Cogswell, M. D. Glascock, E. Skokan, S. Mulholland, R. Rogers, and B. Nelson, pp. 273-288. Document No. 970849. Espey, Huston \& Associates, Inc., Austin.

Skokan-Switek, E.

1997a Results of the Petrographic Analysis of Ceramics from Site 41RK342, Rusk County, Texas. In Cultural Resources Investigations of the Oak Hill D-III Permit Area, Rusk County, Texas, by E. A. Skokan, E. Foster, and R. Rogers, Appendix E. Document No. 940002. Espey, Huston \& Associates, Inc., Austin. 
Skokan-Switek, E.

1997b Results of the Petrographic Analysis of Ceramics from Sites 41TT572, 41TT577, 41TT591, 41TT593, and 41TT653, Titus County, Texas. In National Register Testing of Seven Sites in the Monticello B-2 Surface Mine, Titus County, Texas, by V. Galan, R. Rogers, T. K. Perttula, and E. S. Switek, Appendix C. Document No. 971085. Espey, Huston \& Associates, Inc., Austin.

2004 Petrographic Analysis of Ceramics. In The Oak Hill Village Site (41RK214), Rusk County, Texas, by R. Rogers and T. K. Perttula, pp. 295-306. Document No. 930083. PBS\&J, Austin.

Speakman, R. J. and M. D. Glascock

2003 Instrumental Neutron Activation Analysis of Pottery from the Alex Justiss Site (41TT13), Titus County, Texas. MURR, Columbia, Missouri.

Speakman, J. and T. K. Perttula

2003 Results of the Instrumental Neutron Activation Analysis of Caddo Ceramic Sherds from the Hatchel Site. In Archeological Investigations of Village Areas at the Hatchel Site (41BW3), Bowie County, Texas, by T. K. Perttula and B. Nelson, pp. 161-166. Report of Investigations No. 58. Archeological and Environmental Consultants, LLC, Austin.

Steponaitis, V. P., M. J. Blackman and H. Neff

1996 Large-Scale Patterns in the Chemical Composition of Mississippian Pottery. American Antiquity 61(3):555-572.

Stoltman, J. B.

2005 Report on Petrographic Observations of Ceramic Thin Sections from Lake Providence, Louisiana. In Lake Providence: A Terminal Coles Creek Culture Mound Center, East Carroll Parish, Louisiana, edited by R. A. Weinstein, pp. 545-564. Coastal Environments, Inc., Baton Rouge.

Swenson, F. E.

1989 Preliminary Studies in the Use of Petrographic and Proton Induced X-Ray Emission Analysis (PIXE). In Contributions to Spiro Archeology: Mound Excavations and Regional Perspectives, edited by J. D. Rogers, D. G. Wyckoff, and D. A. Peterson, pp. 177-186. Studies in Oklahoma's Past No. 16. Oklahoma Archeological Survey, Norman. 